\title{
Reviewing the Global Smartphone Industry Strategic Implication in Response to COVID-19 Situation
}

\author{
https://doi.org/10.3991/ijim.v15i14.18879 \\ Samsul Alam \\ Daffodil International University, Dhaka, Bangladesh \\ salam.bbaediu.edu.bd
}

\begin{abstract}
The global smartphone brands were progressing aggressively over time. A sudden unexpected turbulent situation known as a global pandemic declared by the World Health Organization (WHO) about a century later in the history of human civilization stops this progress. It makes the industry bound to fall behind. This study aims to review and analyze the impact of the present pandemic situation due to Coronavirus Disease 2019 (COVID-19) on the global smartphone industry. It shows the competitive scenarios focusing on smartphone demand and supply as-well-as suggests a strategic approach to combat this situation. It is done by reviewing the latest literature published explicitly in 2020. The findings of this study reveal a significant negative impact of COVID-19 on global smartphone brands, primarily especially in the big markets of this industry, namely China, India, USA, Europe. Conversely, it can also positively impact the industry, especially in some developing countries. The positivity is seen due to the expanded demand for smartphones in some sectors like education, business, and entertainment media that shifted online. This shifting triggers the user's need to purchase a new smart device. Lastly, based on the understanding of the current scenario, some strategic approaches are discussed. Again appropriate solutions are given for the industry to cope up with the pandemic crisis and, at the same time, attain success. The strategic directions given at the end can be applied to the industry's sustainability and growth.
\end{abstract}

Keywords - Competitive approach, COVID-19 impact, global smartphone brand, pandemic situation, smartphone industry, strategic implication

\section{Introduction}

One of the leading industries in this technological era, the smartphone industry, emerges in the marketplace suddenly and gets the fastest growth besides the internet. It does not have a lengthy historical background. The mobile phone comes into existence by Motorola researcher and executive Martin Cooper on April 3, 1973. After that, mobile phone devices get global acceptance. Likewise, different national and multinational companies start producing commercial mobile phones. Later, Cooper's boss and Motorola's chief of portable communication products played a vital role in advancing the equipment of handheld mobile phones in that same year. Then, Mitch- 
ell pushes Motorola to develop wireless communication products that are small enough to use anywhere and thus participates in the cellular phone design. In this way, Motorola, Inc. (1928, USA) is the first multinational mobile company, but the irony of this pioneering company is that it is not in existence today. It stops its business operations in 2012 by being sold to Google, which Lenovo, later on, acquired in 2014. However, from Smith's [1] report, it is found that the first smartphone is launched by another hi-tech company International Business Machine (IBM), in 1992 by the name of Simon. It incorporates a touchscreen, email, fax, address book, built-in apps, calculator, sketch pad, predictive typing having some limitations of high cost (USD 1,100) and low battery life (1 hour). The real journey of the smartphone starts with tech-giant company Apple's iPhone in 2007 with added features. The smartphone gets much popularity with the inception of android and more mobile phone companies' joining in smartphone production and introduction in the market, allowing customers to purchase a phone with a high-quality camera, much storage capability with a cloud computing facility, strong battery life, Electronic Commerce (E-commerce) transaction capability, location traceability, availability of apps and tools, more customization facility, more support through Artificial Intelligence (AI) technology at affordable prices. Some of the most popular smartphone models are iPhone 5, 6, 6 Plus, 7, 7 Plus, X, XR 11, 11 Pro Max; Samsung Galaxy J2 Core, S III, S4, S7, S8, S8+, S9, S10, S11, S20+, A20, A30s, A50, A51, A10s; Xiaomi Redmi Note 7, 8, 8 Pro; Huawei Mate 10 Pro, P20; Google Pixel 2; OnePlus 5; HTC U11; Nokia 6600, 5230, N70; Motorola Droid Bionic; LG G3; HTC Thunderbolt and many more. Today almost 3.6 billion users (around $45 \%$ of the world population and $67 \%$ of total mobile phone users) among 5.26 (around $67 \%$ of the world population) billion unique mobile phone users of 10.4 billion mobile connections all over the world use smartphone devices [2].

The whole world has been undergoing a pandemic situation since the beginning of 2020 due to COVID-19. Its ongoing spread infects approximately 219 countries, around 76 million cases, caused 1.6 million deaths worldwide till 2020, which reached around 166.9 million infected cases, 3.5 million deaths in May 2021 [3], [4]. By this time, many research activities are conducted throughout the world. Venkatesh [5] studies scientific research on COVID-19 and mentions a moral significance for science to assist people fighting against this tough time and recovering from this pandemic, subsequently settings an agenda for research. He categorizes the agenda into three distinct areas. He provides direction to study on (i) jobs - job loss, job changes, job outcomes, coping, and support, (ii) home life - home life changes, children, and life-related outcomes, (iii) overarching possible research directions and considerations- social life, support focal groups, general issues, and special considerations. According to Research Gate [6] repository, around 269,356 published and working papers till May 2021. These are categorized into many disciplines like machine learning and deep learning $(3,326)$, mobility and location data $(1,128)$, control and exit strategies $(24,591)$, SARS $(15,460)$, MERS $(1,712)$, protecting frontline workers $(10,918)$, psychological impact $(7,184)$, social and economic impact $(17,248)$ and more are being added over time. Although there are many articles published on social and economic impact, no article is explicitly found based on its impact on the global 
smartphone industry. Hence, this paper focuses on social and economic development. Thus, the current study responds to Venkatesh's [5] possible research direction and considerations of changes to social life, support to cope with demand, and role of technology, and Research Gate's [6] repository categorization of social and economic impact.

It can be inferred that the pandemic situation harms the global smartphone industry as it reduces the customers' purchasing power due to income loss, joblessness, economic activity shutdown well as it affects the supply chain. On the contrary, it can positively impact demand for global smartphone brands because of the urgent need for distance learning, works from home, increased communication with dear ones due to lockdown, and increased mobile entertainment for psychological support. Based on the discussion, two research questions are developed. First, what are the actual impacts of COVID-19 on global smartphone brands? Second, what strategic approaches should these companies take during and after the pandemic situation?

Based on the assumptions and research questions, the primary purpose of this study is to show the impact of COVID-19 and analyze the strategic implications of the global smartphone industry. The specific purpose is to discuss the:

- Major global smartphone brands based on industry position

- Global smartphone industry market analysis and competitive scenario

- Significant changes occurred in the industry due to COVID-19

- Significant trends and consequences of the rise of this industry

- Future strategic options of the industry for achieving success

This study includes the smartphone industry throughout the world. It describes the ins and outs of the industry concerning strategy implementation during and after the COVID-19 pandemic situation. Thus, the study outcome is helpful to the industryspecific stakeholders such as smartphone companies' policymakers, suppliers, distributors, research scholars, market analysts, investors, users to understand and tackle present and future scenarios.

The study is constructed systematically. The whole study is chronologically divided into seven parts; formerly, the background shows a historical overview of the global mobile phone industry and an overview of COVID-19. Then, literature from previously conducted studies is explored. Next, the methodology of the study is discussed. After that, an overview of global smartphone brands is given. Then, the impact of COVID-19 on the smartphone industry is shown; subsequently, strategic options are discussed. In the end, a conclusion is drawn, and future research directions are mentioned.

\section{Review of Literature}

Staboulis and Lazaridou [7] mention that it is expected that a pandemic situation occurs in the history of human civilization. Usman et al. [3] conduct a detailed study on the economic impact of COVID-19. Likewise, many other researchers have already worked and have been working on the impact of COVID-19 from an economic 
perspective. The study of Baldwin et al. [8] specifies that just before the pandemic situation, the global economy was rosy, tense free, and cheerful, which situation has changed due to COVID-19. It brings about the most suffering to the economic sector all over the world. It is contagious to the economy as like the medical sector. Where European Union (EU) mentions that Italy and France are at risk of going into an economic recession, International Monetary Fund (IMF) states that there is an extreme chance for a fall of the global economy. Borri [9] mentions that the economic impact of COVID-19 is acute, where Fernandes [10] comments that global recession is almost inevitable. Nicola et al. [11] and Baldwin et al. [8] identify that it has triggered the probability of unwanted economic crisis and recession. Again, the production of commodity and manufacturing products has decreased. In other words, this sector suffers from a triple hit for disruption of direct supply, supply chain contagion, and disruption of demand.

According to Oxford Analytica, [12] "COVID-19 will worsen the global manufacturing downturn". Nicola et al. [11] specify that multinational companies and distributors will manufacture and source beyond China over the years. Baker et al. [13] mention that no infectious disease in the past like the Spanish Flu was as devastating as COVID-19 that affects the stock market severely. A study by Czech et al. [14] identifies continuous pandemic results in the depreciation of Visegrad currencies. Waheed et al. [15] mention that due to COVID-19, stock markets of developed countries go to an uncontrolled situation [16] wherein developing countries like Pakistan has a positive increase in stock returns that is the result of in time response from the government. Elleby et al. [17] specify that due to income loss and supply chain disruption [10], pandemic leads people in developing countries to suffer from food insecurity. However, global food consumption is not so much affected. Saha and Khan [18] conduct a survey and find that people whose regular activity is affected have a financial crisis during the lockdown. Mental health becomes poor, especially for females.

After COVID-19 appeared, few countries pursued a laissez-faire approach, and lately, almost all governments emphasize restrictive controls [12]. Bartik et al. [19] and Vidaurreta et al. [20] study its effect on small businesses and found these businesses are severely affected where many are closed down, and most of the remaining are at risk. Cowling et al. [21] find that 39\% of SME businesses have been strengthening cash balances during the pandemic, where $61 \%$ might run out of cash, involving $8.6 \%$ having no retained earnings mentioning that micro-business companies are at risk. Kabir et al. [22] argue that the pandemic situation will have a long-lasting impact on health hazards, financial difficulty, and future employment opportunities of garment workers in Bangladesh. They suggest that these issues should be considered by stakeholders, e.g., international buyers, BGMEA, and government policymakers. Another study argues that due to coronavirus, Spain's economy is poorly affected and comments that an immediate recovery of the economy is not possible [23].

Kaur et al. [24] mention that COVID-19 has brought about a change in doing business. Kandi and Deogade [25] study a completely different impact of COVID-19, showing the positive impact. They identify a few vehicles on the road due to lockdown, which produce lower air and water pollution, road traffic accidents, and a low crime rate. It facilitates people spending quality time with family members, fulfills 
hobbies, learns many new skills, and understands sanitation necessity, hand hygiene, and social distancing. They conclude that it also reminds us of the need for an improved healthcare system and clinical studies, and improved immunity. This situation shows a short-term emission of greenhouse gas though having no long-term effect. Another study by $\mathrm{He}$ et al. [26] argues that it opens up ample opportunity for businesses to play social responsibility to mitigate a global social and environmental crisis. They also discuss how the pandemic changes the marketing concept, context, and strategies due to COVID-19. Yoo and Managi [27] calculate COVID-19 global mortality benefits using the age- and country-specific Value of a Statistical Life (VSL). They identify that social distancing, home quarantine, school closures, and case isolation may save up nearly USD 40.76 trillion globally. Social distancing accounts for $55 \%$ of benefits and mentions USA, Japan, and China may get the most benefits.

Radanliev et al. [28] study global pandemic management based on a comprehensive bibliographic review and propose solutions to pandemic management in a predictive, preventive, and personalized way based on social machines and connected devices. Budd et al. [29] study digital technologies in response to COVID-19 and mention that enhanced use of mobile phones, substantial online datasets, connected devices, minimum cost computing resources, and machine learning and natural language development can be adopted to tackle the pandemic. McMaster et al. [30] say that COVID-19 has affected supply and demand negatively. They indicate a need for building flexibility to lessen the risk of epidemics. Narang et al. [31] reveal that some companies are more capable of resilience than others and mention that small and low profitable companies are mostly affected. Goyal [32] and Haubrich [33] suggest that it is essential to enhance macroeconomic stimulus and attain financial stability to recover and sustain after the COVID-19 pandemic. McKibbin and Fernando [34] recommend financial institutions to ensure carry-on functioning while pandemic sustains for recovering affected economies. Businesses have pursued innovative ways to achieve success. The pandemic situation has boomed E-commerce businesses, video conferencing platforms, education technology vendors. It is also making a truly digital world as a result of coping with the new normal situation. Pandey [35] specifies that COVID-19 brings about paradigm shifts in the workplace and businesses that need to cope with this change; otherwise, there will be a survival question. Radanliev et al. [28] mention that instead of having and deploying available digital methods for slowing down or clogging COVID-19 and upcoming pandemic, the globe is not prepared, and no lessons have been learned from earlier pandemic cases. Oliver et al. [36] say that mobile data is used to deduce human movement and social interaction.

Cecere et al. [37] discuss the smartphone's evolution from vertical and horizontal innovations and mention that new smartphone models are increasing day by day due to the entrance of new companies. They find fierce competition in horizontal innovations, although perceived nearly the same in vertical innovations, and conclude that no dominant design has been identified yet. Campbell-Kelly et al. [38] study the evolution of the smartphone industry from multi-sided platform theory that analyzes various practical strategies to solve chicken-and-egg problems for mobile OS at the starting point. Based on survey evidence, this theory also examines the approaches used by mobile platforms to continue the momentum with users. This continuance of users' 
momentum is required to involve various user groups. Likewise, they analyze mobile platforms to interact with network carriers, advertisers, and third-party app developers. Finally, they explain Apple's and Google's relative success. Pon et al. [39] conduct a comparative case study in the smartphone industry to analyze platform strategies. They suggest that the OS has aborted to be a bottleneck or control point. Again, OS are contributing to enhancing the popularity of mobile phone brands. Different OS is being used in smartphones like Android, iPhone, BlackBerry, Symbian, Windows, and many more. All of these OSs are not similarly popular throughout the world. For example, Blackberry OS is popular in North America, whereas iPhone OS has recently witnessed a high growth rate in North America [40]. These smartphone companies depend on cloud-based services to create value and lock in users [39]. Park and Koo [41] analyze the smartphone market's OS switching costs using the hierarchical Bayesian multinomial logit model and find it is USD 171, but this cost relies on consumer characteristics. Shin [42] uses the Customer Satisfaction Index (CSI) model for smartphones and finds that perceived value and customer satisfaction are essential variables and the heuristic implication for effective policies and competitive strategies. Other researchers Galetovic et al. [43] find that mobile phone technologies are developed and licensed by specialized companies and estimate an average cumulative royalty yield in the value chain, USD 7.20 per phone (3.3\%) in 2016. They claim that decentralization produces high royalties. Rennhoff and Routon [44] estimate telephone services demand in the USA, where they find a monthly consumer surplus of USD 35.5, which reduced to aggregately USD 7.03 billion from the smartphone's inception. The smartphone is a more substantial substitute for a landline than the featured phone. Thus they suggest that smartphone growth triggered down the growth of landlines.

Funk [45] studies on Japanese mobile phone industry to show how the value network of this industry is changing from the value chain. He shows that many interface standards are creating a relationship between this industry and other industries. He finds that this change needs a different setting standard, making policy, and managing value networks than are used presently in this industry. Again, Narayana [46] studies the Indian public and private sector's growth contributions in telecom services and estimates that demand for socio-economic determinants of these services is fixed. The result shows a strong negative effect on price and a positive effect on income variables. It distinguishes the necessity of social caste, nature of the occupation, level of education, family size, and age of household head between mobile and fixed phones that provide evidence for mobile phones substitutability for fixed phones. Ward [47] finds a considerable impact of mobile phone use on China's economic growth, whereas more minor impacts from fixed-line use. This effect is high when it is a less developed country. They develop an estimation strategy to lower the possible endogeneity bias.

Carton et al. [48] study smartphone usage patterns and future forecasts and find that every fifth person will possess a smartphone globally. This forecasting is based on the unbelievable demand for smartphones, making it a new global tech cycle. Mongardini and Radzikowski's [49] conclude that global smartphone mobile sales maybe peaked. They mention that in 2016 with around 1.5 billion units sold, global smartphone sales fell to around 1.4 billion in 2019, indicating the market has been saturated. In Canalys [50] reports, it is mentioned that in the First Quarter (Q1), Sec- 
ond Quarter (Q2), Third Quarter (Q3), and Fourth Quarter (Q4) of 2020, smartphone shipments fell respectively $14 \%, 15 \%, 1 \%$, and $2 \%$ globally from the same quarter of the previous year. Their further study shows that there will be negative growth of global smartphone brands shortly, at least for five years. This negativity will happen due to the low penetration of users in the market and the high replacement cycle. However, the entrance of 5G may open up a new industry picture with an increased trend of customer demand, and as a result, positive sales growth may occur.

\section{Methods}

\subsection{Smartphone vs. pandemic situation}

The smartphone is a mobile electronic handheld device mainly used for distance communications with some bundle of features. These features may include voice calls, video calls, short messaging service, internet browsing and surfing capabilities, global positioning system, multimedia services (audio-video), camera, and many more. Smartphone has a ubiquitous use throughout the world [51]. The smartphone industry has passed the growth stage of the industry life cycle and exists in the maturity stage. So, the market is much more competitive than earlier [40]. The global smartphone companies face difficulties from the regional smartphone producers. Now the industry has been struggling with the pandemic crisis that originated from COVID-19.

COVID-19 originated and was found in Wuhan, China, on December 31, 2019 [3], [4]. WHO [4] reports that among the infected countries, nearly 54\% are from the top 3 countries, namely the USA, India, and Brazil. Again, around $42 \%$ of people have died from these three countries out of total death cases worldwide. Other countries having high death rates are Mexico, UK, Italy, France, Spain, and Peru, having higher than $20 \mathrm{~K}$ measures. Worldwide, medicine specialists are struggling to invent a vaccine to prevent this virus from almost the beginning of the pandemic, but no success stories have been heard. United Nations [52] reports that this virus will not disappear rather sustain for long-lasting as announced by WHO. Fortunately, the good news is that on August 11, Russian President Vladimir Putin declared that his country approves a vaccine against coronavirus. Although there is controversy about the effectiveness of this vaccine because of its quick launch [53], this initiative show smiles to billions of people worldwide. It works as motivation for other specialists to bring more effective vaccines. Finally, on December 8, 2020, WHO approves the first COVID-19 vaccine. In 2020, 2 vaccines got approval. By May 2021, total 7 vaccines namely (i) COMIRNATY (BioNtech-Germany), (ii) AstraZeneca (Republic of Korea), (iii) COVISHIELD (Serum Institute - India), (iv) Janssen (Belgium), (v) AstraZeneca (Sweden), (vi) Moderna Biotech (Spain), and (vii) Sinopharm (China) get approved [4]. To encapsulate the overall scenario and impact of COVID-19 in the global economy, specifically on the global smartphone industry, and to discuss the strategic implications arising from this pandemic, the author conducts this thorough study. 


\subsection{Design}

To validate assumptions and to answer the research question, it is required to study existing literature in detail. Thus, the study is based on data of already available literature on COVID-19 impact on the global smartphone industry that is a hot topic in the current situation. The systematic literature reviews, a widely accepted method addressed by Kitchenham and Charters [54] and Budgen and Brereton [55], are adopted in this study. As part of this review, the synthesis of both the qualitative and quantitative studies by searching, selecting, systematically reviewing the academic publications from renowned databases and at the same time credible online sources are used.

\subsection{Data}

To retrieve the published literature in the relevant field of COVID-19 and the smartphone industry to find a real scenario, the author searches the literature by using conventional subject searching methods in some reputed databases. In searching the literature, the period is considered from 2014 to 2019 as per the relevance and suitability. From the time interval of 2020, approximately 60 samples are accepted. Then, other time intervals from 2014 to 2019 are also accepted. 3 articles are collected from 2019, 4 from 2018, 6 from 2016, 6 from 2015, and 3 from 2014 are used. Again, other 4 papers are used for 2009, 2007, 2006, and 1989 respectively, whereas the rest are undated.

The sources include various journal articles, books, annual reports, conference papers, websites, newspapers, weblogs, reports, working papers collected from the internet. These data are collected by using appropriate searching words like COVID-19 impact, global smartphone, the economic impact of the pandemic situation, and strategic implications from the world's prominent academic publishers' databases, e.g., Elsevier's Scopus, Clarivate Analytics' Web of Science, Springer, IEEE, Emerald, Google Scholar, Research Gate, and online sources from websites. The strategy of searching this metadata is that they are used in database documents title: smartphone or COVID-19 impact; abstract-keywords: global smartphone brands OR economic impact of the pandemic situation; doctype: article OR conference proceedings; PUBYEAR: $2014<2020$. It is an exploratory study that uses a mixed approach using both qualitative and quantitative data. To discuss and analyze the quantitative data, the author uses time-series data. These data are collected from renowned websites of global smartphone brands like Huawei, Samsung, Apple, Xiaomi, Oppo, Vivo, Realme, Lenovo, LG, ZTE annual reports; third party analysts like Canalys, Counterpoint, International Data Corporation (IDC), Gartner, Statcounter, Statista, and more.

\section{Overview of the Global Smartphone Industry}

A global industry is many companies operating their businesses' functional activities worldwide beyond national boundaries. A company operating under this industry is called a global company. The Motorola company is the first global mobile phone brand in the world. Afterward, different companies started their mobile phone business worldwide. There are many mobile phone companies globally, most of which 
operate their business globally. Among these companies, some are globally recognized. Among all renowned global smartphone brands, the top eleven are tabulated (see Table 1) with some of their particulars. Each smartphone producer designs, develops, and markets several models from time to time. The demand for mobile is the most variable one. That is why a model may exist in the market only for six months or even less.

Table 1. Top branded global smartphone companies with their particulars

\begin{tabular}{|c|c|c|c|c|c|c|c|c|}
\hline SN & $\begin{array}{l}\text { Global } \\
\text { brand } \\
\text { name }\end{array}$ & Founder & $\begin{array}{c}\text { Established } \\
\text { year }\end{array}$ & $\begin{array}{c}\text { Released } \\
\text { year }\end{array}$ & Headquarter & $\begin{array}{c}\text { No. of } \\
\text { markets } \\
\text { served }\end{array}$ & $\mid \begin{array}{c}\text { Yearly } \\
\text { units } \\
\text { shipped } \\
\text { in 2020 } \\
\text { (million) }\end{array}$ & $\begin{array}{c}\text { Top product } \\
\text { models (series) }\end{array}$ \\
\hline 1 & Samsung & $\begin{array}{l}\text { Lee Byung- } \\
\text { Chul }\end{array}$ & 1938 & 1988 & $\begin{array}{l}\text { Seoul, South } \\
\text { Korea }\end{array}$ & 79 & 256 & $\begin{array}{l}\text { Galaxy S, Note, } \\
\text { Z, A, XCover }\end{array}$ \\
\hline 2 & Huawei & Ren Zhengfei & 1987 & 1997 & $\begin{array}{l}\text { Shenzhen, } \\
\text { China }\end{array}$ & 170 & 188 & $\begin{array}{l}\text { Mate, Nova, Y, P, } \\
\text { Enjoy, Lite, } \\
\text { Maimang, As- } \\
\text { cend, U, G, X, M }\end{array}$ \\
\hline 3 & iPhone & $\begin{array}{l}\text { Steve Jobs, } \\
\text { Steve Wozniak, } \\
\text { Ronald Wayne }\end{array}$ & 1976 & 2007 & $\begin{array}{l}\text { California, } \\
\text { USA }\end{array}$ & 40 & 201 & $\begin{array}{l}3 \mathrm{G}, 4,5,6,7,8 \\
\text { SE, } X, 11,12,13\end{array}$ \\
\hline 4 & Xiaomi & Lei Jun & 2010 & 2011 & $\begin{array}{l}\text { Beijing, } \\
\text { China }\end{array}$ & 20 & 145 & $\begin{array}{l}\text { Mi 1, 2, 3, 4, 5, 6, } \\
8, \text { Play, 9, CC9, } \\
10,11\end{array}$ \\
\hline 5 & OPPO & Chen Mingyong & 2001 & 2004 & $\begin{array}{l}\text { Dongguan, } \\
\text { China }\end{array}$ & 31 & 112 & $\begin{array}{l}\mathrm{F} 1,5,7,9,11, \\
15,17, \mathrm{~A} 74\end{array}$ \\
\hline 6 & Vivo & Shen Wei & 2009 & 2009 & $\begin{array}{l}\text { Dongguan, } \\
\text { China }\end{array}$ & 100 & 109 & $\begin{array}{l}\text { V, Y, X, NEX, S, } \\
\text { Iqoo } 3\end{array}$ \\
\hline 7 & Realme & Sky Li & 2018 & 2018 & $\begin{array}{l}\text { Shenzhen, } \\
\text { China }\end{array}$ & 27 & 42 & $\begin{array}{l}1,2, C, U, 3, X \\
5,6,8\end{array}$ \\
\hline 8 & LG* $^{*}$ & Koo In-hwoi & 1958 & 1995 & $\begin{array}{l}\text { Seoul, South } \\
\text { Korea }\end{array}$ & 118 & 55 & $\begin{array}{l}\text { G, V, Stylo, W, } \\
\text { K, Q, X, Tribute, } \\
\text { Candy, Velvet, } \\
\text { Aristo, Wing }\end{array}$ \\
\hline 9 & Lenovo & Liu Chuanzhi & 1984 & 2012 & $\begin{array}{l}\text { Beijing, } \\
\text { China }\end{array}$ & 160 & 50 & VIBE, K, A, Z, P \\
\hline 10 & ZTE & Hou Weight & 1985 & 2002 & $\begin{array}{l}\text { Shenzhen, } \\
\text { China }\end{array}$ & 160 & 45 & $\begin{array}{l}\text { N, Star, Grand X, } \\
\text { Axon, Blade, } \\
\text { Zmax }\end{array}$ \\
\hline 11 & TCL** & Li Dongsheng & 1981 & 2004 & \begin{tabular}{|l} 
Boulogne- \\
Billancourt, \\
France
\end{tabular} & 170 & 20 & $\begin{array}{l}\text { TAB, SIGNA, } \\
\text { MoveTime, } 10, \\
20\end{array}$ \\
\hline
\end{tabular}

*1958-1995 (Lucky-Gold Star), 1995 (renamed LG-Life's Good), **1981 (TTK), (2006 merged in AlcatelLucent enterprise, 2016 acquired by NOKIA)

Source: Adopted from [56], [57], [58], [59], [60], [61], [62], [63], [64], [65] 


\section{COVID-19 Impact on The Smartphone Industry}

Generally, mobile phone companies produce smartphones and feature phones. The global smartphone industry has an increased sales growth over time. Although in 2017, worldwide smartphone declines $0.5 \%$ for the first time Year-Over-Year (Y-oY). However, IDC forecasts mobile phone companies may enjoy a Compound Annual Growth Rate (CAGR) of $2.8 \%$ from 2017 to 2022 with USD 1.68 billion in sales volume in 2022 [56]. Nevertheless, this assumption may not be proved correct, and the reason for this variation is COVID-19.

Framingham [66] reports that the global mobile phone industry suffers a Y-o-Y decline in sales in the Q1 of 2020. Canalys [50], Framingham [66], and John [67] report that global smartphone vendors see a further fall in smartphone sales worldwide inevitably. They mention that global smartphone records worst performance in the Q1 of 2020 with $17 \%$ decline (13\% Y-o-Y decline) and Q2 with $14 \%$ decline (16\% Y-o-Y decline) although Q3 sees a $22 \%$ positive growth (1\% Y-o-Y decline) from the previous quarter. In $\mathrm{Q} 4$, there is a $3 \%$ positive growth (2\% Y-o-Y decline) amid the second wave of pandemics from the previous quarter. In contrast, different scenarios were seen in Q1 of 2021 with a $4 \%$ negative growth (27\% Y-o-Y rise) from the previous quarter. Framingham [66] reports that during the Q1 of 2020, global smartphone brands shipped 275.8 million units of smartphones, with the highest decline ever over the last three years. In Q2, Huawei outperforms Samsung for the first time with 55.8 million units shipment compared to 53.7 million Samsung shipments. It has interchanged in the Q3 when Huawei's shipment falls 23\% Y-o-Y to 51.7 million compared to Samsung's 2\% Y-o-Y up to 80.2 million. Oppo outperforms Vivo in Q2 and vice versa in Q3. In Q4, iPhone outperforms Samsung with 81.8 million unit sales, 19.8 million up from Samsung that position reversed in Q1 of 2021 with 76.5 million sales and 24.1 million up from iPhone. Overall, in 2020 amid pandemic, the global smartphone brands' growth is negative ( $2 \%$ Y-o-Y decline). Individual annual brandwise growth perspectives as: Samsung (256 million, 14\% decline), iPhone (207 million, 5\% growth), Huawei (189 million, 22 decline) Xiaomi (150 million, 19\% growth), Oppo (115 million, 4\% decline), others (349 million, 9\% decline). Egham [68] writes, "global smartphone sales declined $20 \%$ in the Q1 of 2020 due to covid-19 impact". Figure 1 shows the growth scenario of global smartphone shipments.

In Q1, the world's largest market of this industry, China, experiences an $18 \%$ drop in shipments when this country was in the most affected zone. Next, the USA and Western Europe also experience drastically decline with around $16 \%$ and $18 \%$. In Q3, global shipments have risen to 348 million units, Q4 359.6 million units, Q1 of 2021 347 million units [50]. In Q3, the China smartphone market again experiences an 8\% declined in the shipment (15\% Y-o-Y decline), Q4 decline 4\% Y-o-Y fall when Q1 of 2021 sees a $27 \%$ rise. Overall, China's smartphone market is shrunk by $11 \%$ (330 million units) in 2020 due to COVID-19. Except for Xiaomi, all other brands' shipments fall in this market in Q3. This quarter, Huawei places top position with 34 million shipments with an $18 \%$ Y-o-Y decline and continues this position in Q4, but Q1 of 2021, Vivo places the first position that secures the second position with 15 million shipments causing a $13 \%$ decline in Q3, third position in Q4. Oppo ships 14 million 
with an 18\% decline in Q3, although it has 20\% in Q4 and 22\% growth in Q1 in 2021. Xiaomi ships 11 million with $19 \%$ growth in Q3 and $15 \%$ in consecutive quarters. Apple's shipment in Q3 is 5 million, having a 1\% fall, $18 \%$ growth in the next quarter, and $13 \%$ growth in the consecutive quarter. Other brands ship 4.8 million in Q4 with 6\% growth (25\% Y-o-Y decline), where Q1 of 2021 has $11 \%$ growth (146\% Y$\mathrm{o}-\mathrm{Y}$ growth). The following quarters in the Chinese market will see competition with new product launches with innovation for the $5 \mathrm{G}$ launches in the country.

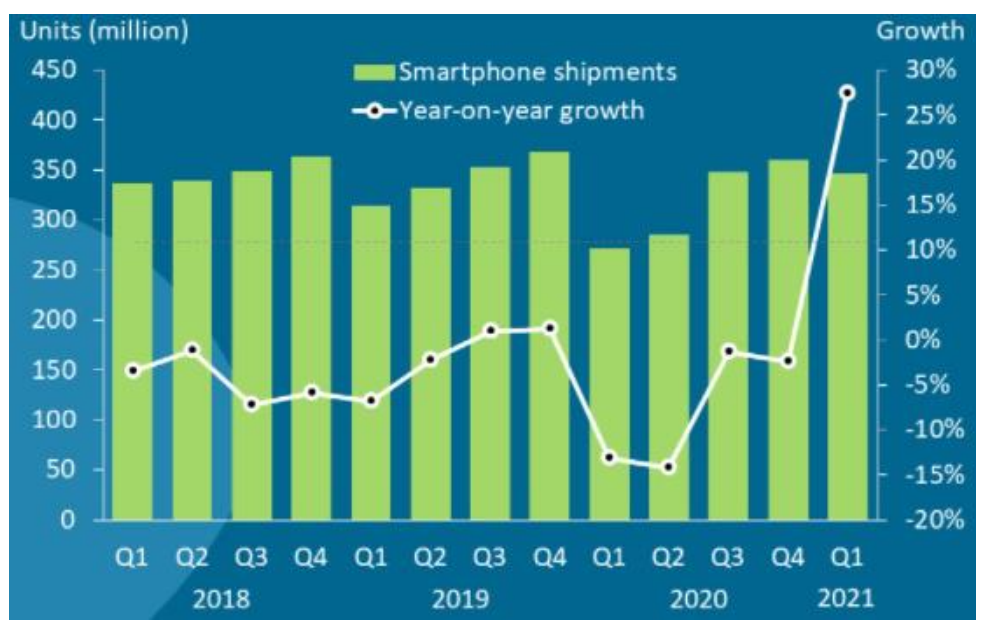

Fig. 1. Quarter-wise scenario for smartphones in respect to units shipped

Source: Canalys and IDC [50], [56]

Singh [69] reports that the world's second-largest smartphone market, India, is tremendously affected by COVID-19 falling its sales by $48 \%$ in the Q2 of 2020 compared to the likely quarter of the previous year. Nearly 17.5 million smartphones are shipped, down from 33 million in the same quarter of 2019 that was 33.5 million in Q1 in 2020. This frustrating scene has changed drastically in Q3 with an 8\% growth rate. Surprisingly, its shipments rise (13\% Y-o-Y growth) in Q4 with 43.9 million smartphones. However, in Q1, India was not mostly affected; rather, their shipments grow by $4 \%$. On the contrary, Canalys [50] reports that India experiences a $48 \%$ decline in the Q2, 50.6\% according to John [67], with 18.4 million units shipped compared to 36.8 million in the previous year. Xiaomi, India's largest smartphone vendor since 2018, ships the largest quantity in Q2, declining around 29.4\% market share [67]. Xiaomi sells additional 14.5 million units in Q3 from the previous quarter, making it the leading position, whereas 12 million shipped in Q4. The second dominant company, Samsung, which once occupies $26.3 \%$ of the market share, declines shipment by $48.5 \%$ Y-o-Y in Q2. Nevertheless, in the third and fourth consecutive quarters, Samsung regains its second position. This change occurs due to demand fluctuation for increasing sales of non-Chinese products for anti-Chinese sentiment in India. Again, Samsung ramps up low to mid-ranged products with an additional discount and other facilities. Vivo captures around $21.5 \%$ market share with 3.7 million unit 
shipment in Q2 remains at the same position with around $18 \%$ incremental sales in third and Q4. Subsequently, Realme and Oppo gain 17\% and 6\% growth, respectively place fourth and fifth positions in Q2 and Q3, whereas Oppo places the fourth position in Q4 with $13 \%$ market share (23\% Y-o-Y growth). To recoup the loss, most of the brands introduce new models in the country. These smartphone companies, e.g., Xiaomi, Vivo, Oppo, and more, might avoid backlash as other atypical companies like Samsung, Nokia, Apple are very price competitive. Apple's iPhone that covers only a $1 \%$ share in India's market, still dominates the premium segment of the smartphone market, is affected with a $20 \%$ Y-o-Y fall in shipment in Q2. It regains momentum with 0.8 million sales in the Q3 due to opening a direct online store. However, it needs to focus on revising its pricing strategy to keep this position sustainable.

Samsung News Room [70] publishes the world's largest global smartphone brand quarterly data. According to the report, Samsung's smartphone profitability remains solid in Q2 with increased shipments among the market competition in the Q3 of 2020. The demand for the smartphone in North American, European, and global markets decreases Quarter-over-Quarter (Q-o-Q) amid lockdown situation despite reduced marketing costs and offline promotions and efficient cost management make it possible for solid profits. It suffers from a $29 \%$ decline in global shipment Y-o-Y in Q2, $2 \%$ positive growth in Q3, and a $12 \%$ fall in Q4 [67]. Hence, this company expects to achieve increased smartphone sales anchored by a strong product mix introducing flagship, galaxy note, and foldable phone models [68]. Although uncertainty persists, the next quarter's overall market will recover gradually by responding to demand in various regions by strengthening the market lineup amid COVID-19. Samsung explores business growth opportunities instead of delayed deployment of 5G services due to coronavirus pandemic globally. Shortly after this initiative, the company overcomes its challenges in Q3 with 80 million shipments in this pandemic situation. From the industry participation and performance, Samsung's global smartphone industry position is first.

Apple was affected by closing their factories in China temporarily, resulting in supply constraints and negative sales growth of 41 million units (8.2\%). iPhone starts global momentum at the eve of 2020, introducing a new product line and online channel that help the company reach record level (25\% Y-o-Y growth) in the Q2 when they ship 45.1 million units. The scenario slightly changes in the Q3, with around 43 million shipments, a 1\% Y-o-Y decline. Apple's iPhone 11 continues best seller at nearly $40 \%$ of their total sales volume. Overwhelmingly, iPhone's salsas reach 81.8 million (4\% Y-o-Y growth) in Q4, recognizing it at top position due to its explicit demand for iPhone 12. This performance gives it the second position in the industry with 5\% Y-o-Y annual growth in 2020.

Huawei, the world's third (first in Q2, second in Q3, and third in Q4) largest smartphone company, sales decline to 42.5 million units $(27.3 \%$ Y-o-Y decline) in the Q1 of 2020, with a $14.2 \%$ market share. Its total shipment records 56 million in Q2, 52 million in Q3, and 32 million in Q4 with a 30\%, 23\%, 63\% Y-o-Y fall, respectively, the worst performer in the year (22\% Y-o-Y decline) among top brands. It has launched the Huawei Mobile Service (HMS) ecosystem, but it cannot create new buyers globally with a lack of Google apps and Google play store. Oppo faces a 
$19.1 \%$ decline in smartphone sales, but its online channel will strengthen its sales volume. Base on the performance of Huawei, it places $3^{\text {rd }}$ in the industry.

Egham [68] reports that people stop buying nonessential products at the first spike of COVID-19 and decline consumer spending because of global shelter-in-place. How can these issues affect this industry? A general analysis is shown in Table 2. The table shows that the top 11 global smartphone brands occupy more than $80 \%$ in 2018 , around $90 \%$ in 2019 , and around $84 \%$ in 2020 global market share. Samsung ranks top in the Q3 of 2020 with a $23 \%$ market share, and Huawei second having a market share of $15 \%$ though Huawei achieves a top position in the Q2 [67]. Other popular brands are having a market share of around $12 \%$ by iPhone, $14 \%$ by Xiaomi, $8 \%$ by Oppo, $9 \%$ by Vivo, $2 \%$ by Realme, $2 \%$ by LG, $1 \%$ by Lenovo, and remaining by ZTE, TCL, Nokia, Sony, Micromax, Asus, Mobicel, General Mobile, Google Pixels, and so forth [63]. From the table, we can guess that between 2018, 2019, and 2020 there are some differences in performance among top giant smartphone companies. At each quarter, some variation in smartphone brands' performance is seen. A Q-o-Q decline in smartphone shipments to market as $13 \%$ in Q1, $14 \%$ in Q2, $1 \%$ in Q3, and $2 \%$ in $\mathrm{Q} 4$, resulting in a 7\% annual decline. But an exception is seen in Q1 of 2021 with 27\% Q-o-Q growth. Significant differences are seen in the Q4 of 2019, Q1, and Q2 of 2020 regarding units sold, resulting in changing revenue and profit, and market sharing. As we know, COVID-19 first infects at the end of the last quarter of 2019 and spread worldwide quickly. The significant differences are seen afterward. This scenario illustrates the negative impact of COVID-19 on smartphone companies in the earlier quarters of 2020, which has started to overcome in later quarters. Although the actual impact can be measured after the pandemic situation overcomes with in-depth analysis based on time series data, we can say that this effect is not as alarming as other industries as we see surrounding us.

Many industries are badly affected by COVID-19, such as the manufacturing sectors like readymade garments, footwear, apparel, jewelry, accessories. Then, service sectors like education, restaurant, tourism, transport, especially civil aviation [71], film and media; bureaucratic relationship like export-import, expatriate. We can see that some sectors like technology, treatment, medicine, e-learning, social media, working at home have been increased. As COVID-19 harms the physical classroom, educationalists explore and find alternative ways of delivering lectures through online platforms. In this perspective, demand for smartphone devices has increased many folds among students and teachers of all levels from schools to universities [72].

Mobile Learning (M-learning) uses mobile devices like smartphones, tablets, PDAs, MP3s, and pocket PCs in teaching and learning to study and practice [76]. It allows students anytime, anywhere, learning opportunities without limitations [76]. M-learning applications are an effective tool for learning and teaching in preschool education. According to Global System for Mobile Communications (GSM), Mlearning helps teach children as it helps in enhancing motivation, fluency, collaboration, and reading skills [77]. Students also recognize these applications as the fulfillment of their educational requirements [78]. Karabatzaki et al. [79] mention that the quick penetrations of smart devices among student folks enable designing proper learning methods to improve their learning. The study of Rojas-Osorio and Alvarez- 
Risco [80] finds that students' continuance intention of using the smartphone of Peruvian university is influenced significantly by perceived ease of use, perceived usefulness, and attitude toward using a smartphone.

Table 2. Top listed global smartphone brands market analysis showing pandemic impact

\begin{tabular}{|c|c|c|c|c|c|c|c|c|c|c|c|c|c|c|c|c|c|c|c|c|c|c|}
\hline \multirow{2}{*}{$\begin{array}{l}\mathbf{S} \\
\mathbf{N}\end{array}$} & \multirow{2}{*}{$\begin{array}{l}\text { Global } \\
\text { Mobile } \\
\text { Brand }\end{array}$} & \multicolumn{10}{|c|}{ Yearly Units Sold (units in millions) } & \multicolumn{3}{|c|}{$\begin{array}{c}\text { Yearly Sales } \\
\text { Revenue (USD } \\
\text { in billion) }\end{array}$} & \multicolumn{3}{|c|}{$\begin{array}{c}\text { Yearly Net } \\
\text { Income (USD } \\
\text { in billion) }\end{array}$} & \multicolumn{5}{|c|}{ Market Share (\%) } \\
\hline & & $\begin{array}{l}Q \\
1- \\
18\end{array}$ & $\begin{array}{c}Q 4 \\
-18 \\
\end{array}$ & $\begin{array}{l}Q 1 \\
-19\end{array}$ & $\begin{array}{l}Q 2 \\
-19\end{array}$ & $\begin{array}{r}Q 3 \\
-19\end{array}$ & $\begin{array}{l}Q 4 \\
-19\end{array}$ & $\begin{array}{c}Q 1 \\
-20\end{array}$ & \begin{tabular}{c|}
$Q 2$ \\
- \\
20
\end{tabular} & $\begin{array}{c}Q 3 \\
- \\
20\end{array}$ & $\begin{array}{c}Q 4 \\
- \\
20\end{array}$ & 2018 & 2019 & 2020 & $\begin{array}{c}201 \\
8\end{array}$ & $\begin{array}{c}201 \\
9\end{array}$ & $\begin{array}{c}202 \\
0\end{array}$ & $\begin{array}{c}Q 1 \\
- \\
18\end{array}$ & \begin{tabular}{c|}
3 \\
- \\
19
\end{tabular} & $\begin{array}{c}Q 2 \\
-20 \\
\end{array}$ & $\begin{array}{r}Q 3 \\
-20 \\
\end{array}$ & $\begin{array}{c}Q 4 \\
- \\
20\end{array}$ \\
\hline 1 & & 78 & 70 & 72 & 76 & 78 & 70 & 59 & 54 & 80 & 63 & 209.2 & $\begin{array}{c}195 \\
2\end{array}$ & \begin{tabular}{|c|}
200. \\
6 \\
\end{tabular} & 38.0 & 18.4 & 22.4 & 31 & 32 & 20 & 23 & 17 \\
\hline 2 & iPhone & 52 & 66 & 42 & 37 & 45 & 72 & 40 & 38 & 43 & 82 & 265.6 & \begin{tabular}{|c|}
260 \\
2
\end{tabular} & \begin{tabular}{|c|}
274. \\
5
\end{tabular} & 59.5 & 55.3 & 57.4 & 19 & 22 & 14 & 12 & 23 \\
\hline 3 & Huawei & 39 & 60 & 39 & 57 & 67 & 56 & 49 & 56 & 52 & 33 & 105.2 & $\begin{array}{c}123 \\
6\end{array}$ & \begin{tabular}{|c|}
136. \\
7
\end{tabular} & 8.5 & 9.0 & 9.9 & 6 & 10 & 20 & 15 & 9 \\
\hline 4 & Xiaomi & 28 & & & 32 & 32 & & & 29 & 47 & 43 & 25.2 & 29.6 & 38.3 & 1.9 & 1.5 & & 0 & & 10 & & 12 \\
\hline 5 & Ora & 24 & & & & 32 & 31 & 22 & 24 & 31 & 34 & 60.0 & 60.0 & 60.0 & .4 & & & 4 & & & & 9 \\
\hline 6 & \begin{tabular}{|l|} 
Vivo \\
\end{tabular} & 19 & 27 & 24 & 27 & 31 & 32 & 22 & 23 & 32 & 33 & 46.5 & 46.5 & 46.5 & 1.1 & 1.1 & 1.1 & 8 & & 7 & 9 & - \\
\hline 7 & Realm & - & - & 3 & 5 & 10 & 8 & 7 & 6 & 15 & 14 & - & - & 20.0 & - & - & 0.3 & - & 2 & 2 & & - \\
\hline 8 & LG & - & - & - & - & - & - & - & - & - & & 51.7 & 52.5 & 46.8 & 1.2 & 0.2 & 0.1 & 3 & 2 & 2 & & - \\
\hline 9 & Leno & - & - & - & - & - & - & - & - & - & & 51.0 & 50.7 & 43.0 & 0.8 & 1.0 & .5 & 3 & & & - & - \\
\hline 10 & & 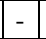 & - & - & - & - & - & - & - & - & & 12.3 & 13.1 & 17.1 & 1.0 & 0.8 & 0.7 & & 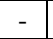 & - & - & - \\
\hline 11 & TCL & - & - & - & - & - & - & - & - & - & & 0.6 & 0.78 & & ( & & & 1 & - & - & - & - \\
\hline 12 & Others & \begin{tabular}{|c|}
12 \\
2 \\
\end{tabular} & 116 & 88 & 93 & 85 & 99 & 67 & 47 & 66 & 93 & & - & & & - & & 19 & 11 & 16 & 27 & 30 \\
\hline 13 & $\mathbf{T}$ & \begin{tabular}{c|}
38 \\
0
\end{tabular} & 395 & 341 & 357 & 380 & 401 & 295 & 276 & 366 & \begin{tabular}{|c|}
39 \\
5
\end{tabular} & & - & & & - & & 100 & 100 & 100 & 100 & $\begin{array}{c}10 \\
0\end{array}$ \\
\hline
\end{tabular}

Source: Adopted from [50], [56], [63], [61], [73], [57], [59], [58], [60], [74], [62], [64], [65], [75]

A study by Alwraikat and Al Tokhaim [81] reveals that the faculty members' attitudes of King Saud University in Saudi Arabia for mobile learning are positive. Polyakova [82] states, "industry 4.0 needs now or will need in the immediate future Education 4.0" (p. 5), and this concept is much appropriate than ever before in recent time due to rapid societal changes for the increasing spread of COVID-19 throughout the world. TV news performed by Sarowar [83] reports on August 14 that in Bangladesh, people's dependency on technology has increased due to COVID-19. However, it has confined their lives because they are dependent on online platforms to remove their stagnation to bring normality in schooling, shopping even in treatment. As a result, despite COVID-19 reducing the ability to buy, it enhances the demand for smartphones, laptops, and other smart online gadgets. As a smartphone is cheaper than a laptop that can fulfill the demand for online classes, shopping, and office work, people get interested in purchasing it. This demand is increased as markets start to open from May 10 partially and almost fully after Eid-Ul-Adha, and consequently, people start purchasing a new smartphone. Wieland and Kollias [84] study online learning before, during, and after COVID-19, indicating that people are pushed to online platforms overnight during this pandemic. Especially in teaching-learning 
phenomena, and it is predicted that after the pandemic, we will experience refinement in teaching and engaging students due to our settlement in the new normal. When face-to-face classes resume, there will be a dramatic shift in setting up safeguards to ensure only online mode at any time and keep the best practices that already have been achieved. Thus the necessity and use of smartphones will persist.

\section{Strategic Directions and Recommendations}

\subsection{Competitive approaches}

Strategy is an ancient concept. It is a military term. Chinese military general and philosopher Sun Tzu (545 BC-470 BC) wrote a book named "The Art of War," which is considered as the basis of strategy. Military people use this term to defeat enemies in the war these days and also today. Likewise, business people started using this term to outcompete rivals and achieve success in their business. Hill et al. [85] define strategy as a course of actions used to outcompete rivals. These actions include attracting and pleasing customers, competing successfully, conducting operations efficiently, and achieving targeted performance levels.

Strategic management is the strategic decision of strategic leaders to formulate and implement strategies. They also mention that competitive advantage is the ability of a company to outperform its competitors to earn higher margins. The source of this advantage is to create value for customers. A sustained competitive advantage comes from maintaining these higher margins over a more extended time. Porter [86], the Harvard business school professor, introduces the five competitive forces model widely known as Porter's five competitive forces model. According to him, the idea of developing a strategy is to sustain the competitive advantage. Intense competition is not an unusual thing, although it is a common problem for the industry. Due to the COVID-19 pandemic situation in the current time, the pattern of competition in the smartphone industry has increased many folds, and companies need to adapt strategies to sustain and achieve success in this situation. Porter's five forces model is used as a framework for assessing and evaluating a company's competitive position. Hence it is recommended for industry participants to follow the widely accepted model as this model is beneficial for smartphone companies to strengthen their market position. As suggested by Porter in 1976, the five forces are discussed herein in light of the global smartphone industry from a strategic perspective.

Any time new companies can enter into the industry and create a threat for existing companies is known as potential new entrants. These companies are not in the industry now, but they can choose to enter as they have the capability. Nowadays, we see many emerging smartphone companies entering the industry by adding facilities for users. Any time a new company may expand its business globally with many innovative products with superior quality can threaten existing top-ranked brands. To deal with this threat, existing global brands can use the capability of achieving economies of scale, brand loyalty, absolute cost structure. It is hard for the potential new entrant to be a new market participant in a current turbulent situation. The economic condi- 
tion has been worsening; hence, global smartphone brands need not worry about this force.

When other industry products fulfill the same kind of buyer needs is known as $s u b$ stitute products. Close substitutes create a powerful competitive weapon as they limit companies' prices for their product. Other things being equal, companies in the industry have the opportunity to raise prices and earn additional profits [87]. The smartphone industry has the substitute products like laptops, tablet PC, desktop computers, and internet communication sites and apps. Already this industry is prevalent over these substitute products for their acceptance as most effective mobile nature to customers; it requires a bit of emphasis on this force, especially in the COVID-19 situation. Hence to reduce the risk of substitute products, the industry should have a good policy.

The parts, materials, components, labor are supplied from the suppliers that possess some kind of bargaining power. Suppliers become powerful when their supplied products are vital for the industry where there are very few suppliers, and the industry is not an essential buy for suppliers [87]. Most global smartphone companies produce the required raw materials on their own; thus, the dependency on suppliers is less, and suppliers cannot apply bargaining power to the significant global smartphone companies.

Smartphone industry products can be bought by companies like a wholesaler, distributor, or consumer. These buyers are influential when they are dominant [87]. In general, global smartphone brands sell their products through their outlets and with other independent distributors. In this case, the buyer can have relative bargaining power on their business activity as they have little or no switching costs. However, the industry needs to please the end-users by providing quality products at a low cost to satisfactory post-sale services. This force is crucial because achieving customer satisfaction is very important to retain existing customers and create new customers. The maximum success of smartphone brands depends on achieving buyers' satisfaction. So, it is recommended for global smartphone producers to focus on managing the bargaining power of customers both in the pandemic situation and in a new normal situation to become successful. In response, they should enhance their product quality, be more responsive to customer needs, become more efficient, and reduce cost.

The most challenging task of any company is to compete in the industry with existing competitors. This challenge results in rivalry among existing industry participants. The intensity of the other four forces also puts pressure on this force. For this industry, except for the bargaining power of customers, no other forces are crucial to hinder its progress. We see massive competition among the existing smartphone industry participants worldwide to gain market share in this industry. The top-rated global smartphone brands have been successfully operating their businesses, likely Samsung, Huawei, iPhone, Xiaomi, Oppo, and others. Nevertheless, exceptions seen like Nokia, Microsoft, and Motorola could not stand out. As discussed earlier, coronavirus has changed the way of doing business; it also intensifies competition among existing companies. So, it is evident that there is vast rivalry among existing global smartphone companies. Here, to become successful, companies must adopt a viable strategy. 


\subsection{Strategic approaches}

The five generic competitive approaches suggested by Thompson and Strickland [87], which is an author-expanded version of a three-strategy classification discussed by Porter [86], stand out. It is also recommended that smartphone companies adopt any of the approaches based on the resource strength and market position. Each of these approaches stakes out a different market position. Each involves distinctively different approaches to competing and operating the business. Firstly, this strategy is not feasible for top-listed brands in a low-cost provider strategy for global smartphone brands. Because this strategy can mislead and revert the customers from purchasing with the notion that a cheap product is a bad product, however, it can be a helpful approach for companies lagging far behind industry positions. Secondly, this strategy is very suitable for global brands with much customer reliability and trust in a broad differentiation strategy. They are not price concerned; instead, they focus on product quality and added attributes or features. Top smartphone brands are encouraged to adopt this strategy. Thirdly, the best-cost provider strategy is not suitable for premium product producer companies. Instead, companies having moderate customer confidence in quality and service who are at the same time price-sensitive can pursue this strategy. Fourthly, a focused (or market niche) strategy based on low costs is feasible in markets where niche customer groups are highly-priced sensitive. Companies having low customer trust in quality and service should target to grab these groups' needs. Finally, a focused (or market niche) strategy based on differentiation is effective for those companies that produce highly qualitative products and set premium prices for these products.

According to data from GSMA intelligence [2], the world will be connected by 1.8 billion 5G users by 2025, where developed Asia (50\%), USA (48\%), and Europe $(34 \%)$ will lead the way. As a result, smartphone demand will persist. Considering the current market condition, along with the existing strategy discussed, the author suggests the next strategic moves for the global smartphone industry.

Smartphone companies require, if pandemic sustains longer, resulting in an interruption in the supply of products, finding alternative ways to efficient supply chain network. No current demands should be unmet for a particular brand and model. In this case, routes like self-managed and self-financed cargo may be introduced. Before doing so, it is necessary to get permission by convincing or making a consensus between the industry and government or appropriate regulatory agencies. On the other hand, proactive initiatives and reactive adjustments must be taken to tackle further natural disasters like COVID-19.

To trace and determine the demand requirement, industrialists should focus on online ordering systems globally and regionally. Based on the demand, it is needed to produce the products (pull strategy). A push marketing strategy is not appropriate in this current market situation.

The global smartphone industry must not stop innovation in new products and model launches. Instead, companies should focus on specific customer demand (market niche strategy) to serve them well. In this regard, developing a long-life battery, 
better surfing capability, transparent sound system, supporting all kinds of applications are essential points to consider.

\section{Conclusion and Future Research Direction}

This paper tries to show the global smartphone brands' current market position based on the units sold, revenue generated, profit earned, customer demand, markets served, and market share occupied. Again, the current market situation is discussed in and out of pandemic conditions. Furthermore, the strategic implications during and after the pandemic situation have been outlined. This study is designed to realize the impact of COVID-19 on this industry. From the study, we assume that the industry is neglected due to the pandemic situation. However, other positive impacts are also seen for some other sectors. Like education sectors' going online, telecommunications sectors' increased demand for more communications, other different sectors' work from home creates a dire need for having a smart device as a mandatory tool accelerate the attractiveness for this industry. It has increased demand for global smartphone brands worldwide despite the reduced purchasing ability of customers and impediment of the supply chain. Again, it is also assumed that global brand demand will increase in the future that will sustain for a long time. As a result, the industry will appear more competitive than earlier compared to the pandemic situation.

Consequently, global smartphone brands must be more strategic to outcompete and outperform their rival companies. As we know, the primary competitive weapon and maintaining the quality, efficiency, innovation, and customer responsiveness where the company needs to focus on its outer environment. To cope with this environment, following Porter's forces model and strategic approaches rigorously, along with other suggestions given by the author, might result in an excellent competitive position. As a result, it is expected that the global smartphone brands can sustain in the pandemic time and the new normal situation after COVID-19.

It can be concluded with remarks that our research community can conduct insightful and detailed research in this field of the global smartphone industry rigorously, showing the actual impact of COVID-19 at the end of the pandemic situation from a macro-level perspective. In this case, the research question can be formulated as to what impacts COVID-19 has on the mobile phone industry? An appropriate questionnaire designed should be formulated to collect answer the research question. Again, a more effective strategic direction should be developed to strengthen the industry position. Another important thing this study omits, the industry-specific micro-level analysis that needs to be addressed. In this perspective, the small brands in this industry should be included to visualize the entire scenario in this smartphone industry. The study should focus on collecting primary data from the industry's authentic sources. In-depth interviews with industry participants as well as the customers may be conducted. Again, studies can be conducted at the micro-level based on a single country or market to show the market or company-specific scenario of the smartphone industry. 


\section{$8 \quad$ References}

[1] R. Smith, "IBM created the world's first smartphone 25 years ago," World Economic Forum, March 13 2018. [Online]. Available: https://www.weforum.org. [Accessed November 9 2020].

[2] GSMA Intelligence Data, "GSMA intelligence," November 9 2020. [Online]. Available: https://www.gsmaintelligence.com/data/. [Accessed November 9 2020].

[3] M. Usman, Y. Ali, A. Riaz, A. Riaz and A. Zubair, "Economic perspective of coronavirus (COVID-19)," Journal of Public Affairs, pp. 1-5, June 18 2020.https://doi.org/10. 1002/pa.2252

[4] WHO, "WHO coronavirus disease (COVID-19)," July 29 2020. [Online]. Available: https://covid19. who.int.

[5] V. Venkatesh, "Impacts of COVID-19: A research agenda to support people in their fight," International Journal of Information Management, vol. 55, December 2020.

[6] Research Gate, "COVID-19 research community," Research Gate, [Online]. Available: https://www.researchgate.net/community/COVID-19. [Accessed 15 September 2020].

[7] M. G. Staboulis and I. Lazaridou, "The impact of COVID-19 on economy, employment and new skills," Journal of European Economy, vol. 19, no. 3, pp. 1-13, August 2020.https://doi.org/10.35774/jee2020.03.409

[8] R. Baldwin and B. W. di Mauro, "Economics in the time of COVID-19," Centre for Economic Policy Research, 2020.

[9] N. Borri, "The COVID-19 challenge to european financial markets: Lessons from Italy," in A New World Post COVID-19: Lessons for Business, the Finance Industry and Policy Makers, M. Billio and S. Varotto, Eds., Rome, Innovation in Business, Economics \& Finance, 2020, pp. 137-148. https://doi.org/10.30687/978-88-6969-442-4/010

[10] N. Fernandes, "Economic effects of coronavirus outbreak (COVID-19) on the world economy," SSRN, 2020.

[11] M. Nicola, Z. Alsafi, C. Sohrabi, A. Kerwan, A. Al-Jabir, C. Losifidis, M. Agha and R. Agha, "The socio-economic implications of the coronavirus pandemic (COVID-19): A review," International Journal of Surgery, vol. 78, pp. 185-193, June 2020. https://doi.org/10.1016/j.ijsu.2020.04.018

[12] Oxford Analytica, "COVID-19 will worsen the global manufacturing downturn," Expert Briefings, March 13 Oxford Analytica. R

[13] S. R. Baker, N. Bloom, S. J. Davis, K. Kost, M. Sammon and T. Viratyosin, "The unprecedented stock market reaction to COVID-19," The Review of Asset Pricing Studies, vol. 0, no. 0, pp. 1-17, July 18 2020. https://doi.org/10.1093/rapstu/raaa008

[14] K. Czech, M. Wielechowski, P. Kotyza, I. Benešová and A. Laputková, "Shaking stability: COVID-19 impact on the Visegrad group countries' financial markets," Sustainability, p. 6282, August 4 2020. https://doi.org/10.3390/su12156282

[15] R. Waheed, S. Sarwar, S. Sarwar and M. K. Khan, "The impact of COVID-19 on Karachi stock exchange: Quantile-on-quantile approach using secondary and predicted data," Jounral of Public Affairs, pp. 1-6, August 6 2020. https://doi.org/10. 1002/pa.2290

[16] E. Onali, "COVID-19 and Stock Market Volatility," SSRN, 2020.

[17] C. Elleby, P. I. Domínguez, M. Adenauer and G. Genovese, "Impacts of the COVID-19 pandemic on the global agricultural markets," Environmental and Resource Economics, vol. 76, p. 1067-1079, August 4 2020. https://doi.org/10.1007/s10640-020-00473-6

[18] S. R. Saha and M. M. H. Khan, "Prevalence and determinants of mental distress during COVID-19 outbreak in Bangladesh: Evidence from an online survey," Preprints, 2020. https://doi.org/10.20944/preprints202008.0104.v1 
[19] A. W. Bartik, M. Bertrand, Z. Cullen, E. L. Glaeser, M. Luca and C. Stanton, "The impact of COVID-19 on small business outcomes and expectations," Proceedings of the National Academy of Sciences, vol. 117, no. 30, pp. 17656-17666, 2020. https://doi.org/10.1073/ pnas. 2006991117

[20] I. Vidaurreta, C. de la Fe, J. Orengo, Á. Gómez-Martín and B. Benito, "Short-term economic impact of COVID-19 on Spanish small ruminant flocks," Animals, vol. 10, no. 8, pp. 1-12, 5 August 2020. https://doi.org/10.3390/ani10081357

[21] M. Cowling, R. Brown and A. Rocha, "Did you save some cash for a rainy COVID-19 day? The crisis and SMEs," International Small Business Journal, vol. 00, no. 0, pp. 1-12, August 4 2020. https://doi.org/10.1177/0266242620945102

[22] H. Kabir, M. Maple and K. Usher, "The impact of COVID-19 on Bangladeshi readymade garment (RMG) workers," Journal of Public Health, pp. 1-6, July 312020. https://doi.org/10.1093/pubmed/fdaa126

[23] Oxford Analytica, "Spain's economic recovery from COVID-19 will be slow," Expert Briefings.

[24] N. Kaur, S. L. Sahdev, V. Chaturvedi and D. Rajawat, "Fighting COVID-19 with technology and innovation, evolving and advancing with technological possibilities," International Journal of Advanced Research in Engineering and Technology, vol. 11, no. 7, pp. 395-405, July 2020. https://doi.org/10.34218/ijaret.11.7.2020.039

[25] P. S. Kamdi and M. S. Deogade, "The hidden positive effects of COVID-19 pandemic," International Journal of Research in Pharmaceutical Sciences, vol. 11, pp. 276-279, 2020. https://doi.org/10.26452/ijrps.v11ispl1.2712

[26] H. He and L. Harris, "The impact of COVID-19 pandemic on corporate social responsibility and marketing philosophy," Journal of Business Research, vol. 2020, no. 116, pp. 176182. https://doi.org/10.1016/j.jbusres.2020.05.030

[27] S. Yoo and S. Managi, "Global mortality benefits of COVID-19 action," Technological Forecasting and Social Change, vol. 160, November 2020. https://doi.org/10.1016/j.techfore.2020.120231

[28] P. Radanliev, D. De Roure, R. Walton, M. V. Kleek, M. R. Montalvo, O. Santos, L. Maddox and S. Cannady, "COVID-19 what have we learned? The rise of social machines and connected devices in pandemic management following the concepts of predictive, preventive and personalized medicine," EPMA Journal, vol. 11, p. 311-332, July 302020. https://doi.org/10.1007/s13167-020-00218-x

[29] J. Budd, B. S. Miller, E. M. Manning, V. Lampos, M. Zhuang, M. Edelstein, G. Rees, V. C. Emery, M. M. Stevens, N. Keegan, M. J. Short, D. Pillay, E. Manley, Heymann, D. Heymann, A. M. Johnson and R. A. McKendry, "Digital technologies in the public-health response to COVID-19," Nature Medicine, vol. 26, p. 1183-1192, August 72020. https://doi.org/10.1038/s41591-020-1011-4

[30] M. McMaster, C. Nettleton, C. Tom, B. Xu, C. Cao and P. Qiao, "Risk management: Rethinking fashion supply chain management for multinational corporations in light of the COVID-19 outbreak," Journal of Risk and Financial Management, vol. 13, no. 8, pp. 1-16, August 2020. https://doi.org/10.3390/jrfm13080173

[31] S. Narang, S. Rawat and R. P. Pradhan, "Firm-level immunity to COVID-19 induced uncertainty," Research Square, 2020. https://doi.org/10.21203/rs.3.rs-53169/v1

[32] A. Goyal, "Post Covid-19: Recovering and sustaining India's growth," Indian Economic Review, August 6 2020. https://doi.org/10.1007/s41775-020-00089-Z

[33] J. G. Haubrich, "Financial stability: Risks, resilience, and policy," Federal Researve Bank of Cleveland, 2020. https://doi.org/10.26509/frbc-ec-202022 
[34] W. J. McKibbin and R. Fernando, "The global macroeconomic impacts of COVID-19: Seven Scenarios," SSRN, 2020. https://doi.org/10.2139/ssrn.3547729

[35] M. Pandey, "Pandemic COVID-19 and its Implications on Human Life," in Impact od Covid -19 and Pandemic Lockdown in India, Eureka Publications, 2020, pp. 231-243.

[36] N. Oliver, B. Lepri, H. Sterly, R. Lambiotte, S. Deletaille, M. De Nadai, E. Letouzé, A. A. Salah, R. Benjamins, C. Cattuto, V. Colizza, N. de Cordes, S. P. Fraiberger, T. Koebe, S. Lehmann, J. Murillo, A. Pentland, P. N. Pham, F. Pivetta, J. Saramäki, S. V. Scarpino, M. Tizzoni, S. Verhulst and P. Vinck, "Mobile phone data for informing public health actions across the COVID-19 pandemic life cycle," Science Advances, vol. 6, no. 23, pp. 1-6, June 5 2020. https://doi.org/10.1126/sciadv.abc0764

[37] G. Cecere, N. Corrocher and R. D. Battaglia, "Innovation and competition in the smartphone industry: Is there a dominant design?," Telecommunications Policy, vol. 39, no. 3-4, pp. 162-175, May 2015. https://doi.org/10.1016/j.telpol.2014.07.002

[38] M. Campbell-Kelly, D. Garcia-Swartz, R. Lam and Y. Yang, "Economic and business perspectives on smartphones as multi-sided platforms," Telecommunications Policy, vol. 39, no. 8, pp. 717-734, September 2015. https://doi.org/10.1016/j.telpol.2014.11.001

[39] B. Pon, T. Seppälä and M. Kenney, "Android and the demise of operating system-based power: Firm strategy and platform control in the post-PC world," Telecommunications Policy, vol. 38, no. 11, pp. 979-991, December 2014. https://doi.org/10.1016/j. telpol.2014.05.001

[40] Persistence Market Research, "Mobile phone and smart phone market: global industry analysis and forecast 2015 - 2021," Persistence Market Research, 2020. [Online]. Available: https://www.persistencemarketresearch.com/market-research/mobile-phone-smartphone-market.asp. [Accessed August 15 2020]. https://doi.org/10. 1109/iis.2009.98

[41] Y. Park and Y. Koo, "An empirical analysis of switching cost in the smartphone market in South Korea," Telecommunications Policy, vol. 40, no. 4, pp. 307-318, April 2016. https://doi.org/10.1016/j.telpol.2016.01.004

[42] D.-H. Shin, "Effect of the customer experience on satisfaction with smartphones: Assessing smart satisfaction index with partial least squares," Telecommunications Policy, vol. 39, no. 8, pp. 627-641, September 2015. https://doi.org/10.1016/j.telpol.2014.10.001

[43] A. Galetovic, S. Haber and L. Zaretzki, "An estimate of the average cumulative royalty yield in the world mobile phone industry: Theory, measurement and results," Telecommunications Policy, vol. 42, no. 3, pp. 263-276, April 2018. https://doi.org/10.1016/j.tel pol.2018.02.002

[44] A. D. Rennhoff and P. W. Routon, "Can you hear me now? The rise of smartphones and their welfare effects," Telecommunications Policy, vol. 40, no. 1, pp. 39-51, February 2016. https://doi.org/10.1016/j.telpol.2015.11.004

[45] J. L. Funk, "The emerging value network in the mobile phone industry: The case of Japan and its implications for the rest of the world," Telecommunications Policy, vol. 33, no. 1-2, pp. 4-18, 2009. https://doi.org/10.1016/j.telpol.2008.09.002

[46] M. Narayana, "Telecommunications services and economic Growth: Evidence from India," Telecommunications Policy, pp. 115-127, March 2011. https://doi.org/10.1016/j.tel pol.2010.12.001

[47] M. R. Ward and S. Zheng, "Mobile telecommunications service and economic growth: Evidence from China," Telecommunications Policy, vol. 40, no. 2-3, pp. 89-101, March 2016. https://doi.org/10.1016/j.telpol.2015.06.005

[48] B. Carton, J. Mongardini and Y. Li, "A new smartphone for every fifth person on earth: Quantifying the new tech cycle," International Monetary Fund, 2018. https://doi.org/10.5089/9781484339695.001 
Paper-Reviewing the Global Smartphone Industry Strategic Implication in Response to COVID...

[49] J. Mongardini and A. Radzikowski, "Global smartphone sales may have peaked: What next?” International Monetary Fund, 2020.https://doi.org/10.5089/9781513545851.001

[50] Canalys, "Global smartphone market Q2 2020," Canalys, July 31 2020. [Online]. Available: https://www.canalys.com. [Accessed September 15 2020].

[51] [51] S. R. Sobral, "Mobile learning in higher education: A bibliometric review," International Journal of Interactive Mobile Technologies, vol. 14, no. 11, pp. 153-170, 2020. https://doi.org/10.3991/ijim.v14i11.13973

[52] United Nations, "No end in sight to COVID crisis, and its impact will last for 'decades to come'," UN News, August 12020.

[53] C. Zimmer," 'This is all beyond stupid.' experts worry about Russia's rushed vaccine," The New York Times, August 112020.

[54] K. BA and S. M. Charters, "Guidelines for performing systematic literature reviews in software engineering," 2007.

[55] D. Budgen and P. Brereton, "Performing systematic literature reviews in software engineering," in 28th international conference on Software engineering, Shanghai, 2006. https://doi.org/10.1145/1134285.1134500

[56] IDC, "Smartphone market share," International Data Corporation, June 22 2020. [Online]. Available: https://www.idc.com/promo/smartphone-market-share/vendor. [Accessed July $312020]$.

[57] Huawei, "Huawei annual report," Huawei, 2020. [Online]. Available: https://www.huawei. com/en/annual-report. [Accessed October 1 2020]. https://doi.org/10.5622/illnois/97 $\underline{80252043437.001 .0001}$

[58] LG, "Global Investor Relations Financial Information," LG, 2020. [Online]. Available: https://www.lg.com/global/investor-relations-financial-info. [Accessed 1 October 2020].

[59] Lenovo Annual Report, "Investor relations," Lenovo, 2020. [Online]. Available: https://investor.lenovo.com/en/global/home.php.

[60] MBA Skool, “Top 10 best mobile phone brands in 2020,” MBA Skool.com, May 182020. [Online]. Available: https://www.mbaskool.com/fun-corner/top-brand-lists/17610-top-10global-mobile-phone-brands.html. [Accessed July 15 2020].

[61] Macrotrends, "Apple financial statements 2005-2020 | AAPL," Matrotrends, 2020. [Online]. Available: https://www.macrotrends.net/stocks/charts/AAPL/apple/financialstatements. [Accessed 6 November 2020].

[62] Statcounter, "Mobile vendor market share worldwide," Statcounter Global Stats, [Online]. Available: https://gs.statcounter.com. [Accessed September 15 2020].

[63] Statista, "Ranking of leading mobile phone brands worldwide in 2019, by shipments, sales, profit," Statista, 2019. [Online]. Available: https://www.statista.com. [Accessed September 30 2020].

[64] Xiomi, "2020 second quarter and interim results announcement," Xiomi, August 262020. [Online]. Available: https://company.mi.com/en-us/ir/indexContent/. [Accessed September 30 2020].

[65] ZTE, "Investor relations," ZTE, 2019. [Online]. Available: https://www.zte.com.cn/global/about/investorrelations/announcement [Accessed $30 \mathrm{Au}-$ gust 2020].

[66] Framingham, "Worldwide smartphone market suffers its largest year-over-year decline in Q1 2020 due to COVID-19, According to IDC," International Data Corporation, April 30 2020. [Online]. Available: https://www.idc.com/getdoc.jsp?containerId=prUS46264320. [Accessed July 31 2020].

[67] C. John, "The inevitable smartphone slump: q2 2020 sees new lows for mobiles," The Quint, August 11 2020. [Online]. Available: https://www.thequint.com/tech-and-auto/tech- 
Paper-Reviewing the Global Smartphone Industry Strategic Implication in Response to COVID...

news/smartphone-market-shipments-and-performance-second-quarter-2020. [Accessed 31 July 2020].

[68] Egham, "Gartner says global smartphone sales declined $20 \%$ in first quarter of 2020 due to COVID-19 impact," Gartner, June 1 2020. [Online]. Available: https://www.gartner.com/en/newsroom/press-releases/2020-06-01-gartner-says-global-

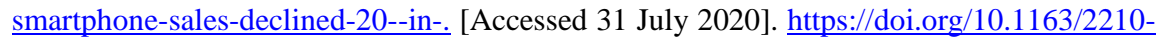
7886_asc-39418

[69] M. Singh, "India smartphone shipments slashed in half in Q2 2020," Tech Crunch, July 17 2020. [Online]. Available: https://techcrunch.com/2020/07/17/india-smartphoneshipments-slashed-in-half-in-q2-2020/. [Accessed August 15 2020].

[70] Samsung News, "Samsung electronics announces second quarter 2020 results," Samsung, July 30 1010. [Online]. Available: https://news.samsung.com/global/samsung-electronicsannounces-second-quarter-2020-results. [Accessed August 15 2020]. https://doi.org/10. 31613/ceramist.2018.21.1.05

[71] A. Abu-Rayash and I. Dincer, "Analysis of mobility trends during the COVID-19 coronavirus pandemic: Exploring the impacts on global aviation and travel in selected cities," Energy Research \& Social Science, vol. 68, October 2020. https://doi.org/10.1016/j. erss.2020.101693

[72] D. Truong, "How to design a mobile application to enhance teaching and learning?" International Journal of Emerging Technologies in Learning, vol. 9, no. 3, pp. 4-11, 2014.

[73] Counterpoint, "Global smartphone market share: By quarter," Counterpoint, August 18 2020. [Online]. Available: https://www.counterpointresearch.com/global-smartphoneshare/. [Accessed September 12 2020].

[74] Samsung, "Financial statements," Samsung, February 25 2020. [Online]. Available: https://www.samsung.com/global/ir/financial-information/audited-financial-statements/. [Accessed July 15 2020]. https://doi.org/10.4160/9789290605980

[75] S. Alam, "Strategic implication of the global mobile phone industry: Analyzing COVID19 impact from competitive viewpoint," Zenodo, Genève, 2020.

[76] S. S. Oyelere, J. Suhonen and E. Sutinen, "M-learning: A new paradigm of learning ICT in Nigeria," International Journal of Interactive Mobile Technologies, vol. 10, no. 1, pp. 35 44, 2016. https://doi.org/10.3991/ijim.v10i1.4872

[77] A. Drigas and G. Kokkalia, "Mobile learning for special preschool education," International Journal of Interactive Mobile Technologies, vol. 10, no. 1, pp. 60-67, 2016. https://doi.org/10.3991/ijim.v10i1.5288

[78] A. Dirin and M. Nieminen, "mLUX: Usability and user experience development framework for m-learning," International Journal of Interactive Mobile Technologies, vol. 9, no. 3, pp. 37-51, 2015. https://doi.org/10.3991/ijim.v9i3.4446

[79] Z. Karabatzaki, A. Stathopoulou, G. Kokkalia, E. Dimitriou, P. I. Loukeri, A. Economou and A. Drigas, "Mobile application tools for students in secondary education. An evaluation study," International Journal of Interactive Mobile Technologies, vol. 12, no. 2, pp. 142-161, 2018. https://doi.org/10.3991/ijim.v12i2.8158

[80] M. Rojas-Osorio and A. Alvarez-Risco, "Intention to use smartphones among Peruvian university students," International Journal of Interactive Mobile Technologies, vol. 13, no. 3, pp. 40-52, 2019. https://doi.org/10.3991/ijim.v13i03.9356

[81] M. Alwraikat and H. Al Tokhaim, "Exploring the potential of mobile learning use among faculty members," International Journal of Interactive Mobile Technologies, vol. 8, no. 3, pp. 4-10, 2014. https://doi.org/10.3991/ijim.v8i3.3682

[82] T. Y. Polyakova, "Engineering Pedagogy: On the Way to "Education 4.0"," International Journal of Engineering Pedagogy, vol. 10, no. 4, pp. 4-8, 2020. 
[83] A. Sarowar, "BanglaVision News," Dhaka, 2020.

[84] N. Wieland and L. Kollias, "Online Learning Before, During and After COVID-19: Observations Over 20 Years," International Journal of Advanced Corporate Learning, vol. 13, no. 2, pp. 84-92, 2020. https://doi.org/10.3991/ijac.v13i2.16779

[85] C. W. L. Hill, M. A. Schilling and G. R. Jones, Strategic Management: Theory \& Cases: An Integrated Approach, vol. 12, Massachusetts: Cengage Learning, 2016.

[86] M. E. Porter, "How Competitive Forces Shape Strategy," in Readings in Strategic Management, London, Palgrave, 1989, pp. 133-143. https://doi.org/10.1007/978-1-349-20317$\underline{8 \_10}$

[87] Thompson, M. Peteraf, J. Gamble and A. Strickland, Crafting and Executing Strategy: The Quest for Competitive Advantage: Concepts and Cases, vol. 20, McGraw-Hill Education, 2015.

\section{Author}

Samsul Alam is a Senior Lecturer (MIS) at the Department of Business Administration, Daffodil International University, Bangladesh. His current research interests cover many research topics in the Management Information Systems and business fields, including digital education, fintech, E-commerce, smart city/home, IoT, ethics, telecommunications, ERP, global economy, and other business and social sciencerelated contemporary issues and thoughts. Email: $\underline{\text { salam.bba@ diu.edu.bd }}$

Article submitted 2020-09-26. Resubmitted 2021-05-26. Final acceptance 2021-05-26. Final version published as submitted by the authors. 